\title{
PLANT FOOD RESOURCES AND THE DIET OF A PARROT COMMUNITY IN A GALLERY FOREST OF THE SOUTHERN PANTANAL (BRAZIL)
}

\author{
RAGUSA-NETTO, J. and FECCHIO, A. \\ Departamento de Ciências Naturais, Campus Três Lagoas, UFMS, C. P. 210, CEP 79600-000, Três Lagoas, MS, Brazil \\ Departamento de Biologia, CCBS/UFMS, C. P. 549, CEP 79070-900, Campo Grande, MS, Brazil \\ Correspondence to: José Ragusa-Netto, Departamento de Ciências Naturais, Campus Três Lagoas, UFMS, \\ C. P. 210, CEP 79600-000, Três Lagoas, MS, Brazil, e-mail: forpus@ ceul.ufms.br \\ Received April 11, 2005 - Accepted May 13, 2005 - Distributed November 1, 2006
}

(With 2 figures)

\begin{abstract}
Neotropical parrots usually forage in forest canopies for nectar, flowers, leaves, fruit pulp, and seeds. As they have no all-purpose territories, these birds usually exploit vegetation mosaics in order to use plentiful resources as they become available. In this study we examine the use of a gallery forest in the southern Pantanal (Brazil) by a diverse parrot community that ranged from Brotogeris chiriri (a small species) to Ara chloroptera (a large one). Plant food resources principally used by parrots were abundantly available during the rainy season (fleshy fruits), the annual floods (fleshy fruits), and the dry season (flowers). While both smaller and larger species foraged on fruits, parakeets largely consumed the pulp, while larger parrot species used pulp and seeds. In the dry season parakeets foraged extensively on nectar, especially Inga vera nectar that was abundantly available during the last two months of the dry season, the harshest period of the year. Among larger parrots, only Propyrrhura auricollis frequently harvested nectar. Fruits maturing during floods, despite being fish- or water- dispersed were extensively used by the parrots. Hence, unlike what happens in most other Neotropical dry forests, occurrence of a fruiting peak during the annual flooding, which occurs in the transition from the wet to the dry season, constitutes an extra and significant episode of food availability, since in this period, fruit production normally declines. Therefore, the unique and abundant availability of flowers and fruits in this gallery forest may account for the presence of large parrot populations in the southern Pantanal.
\end{abstract}

Keywords: Psittacidae, parrot commuity, feeding ecology, gallery forest, canopy phenology, Pantanal.

\section{RESUMO}

\section{Recursos alimentares e dieta de uma comunidade de psitacídeos em uma mata ciliar no Pantanal Sul (Brasil)}

Psitacídeos neotropicais usualmente exploram o dossel das florestas em busca de alimentos como néctar, flores, folhas, polpa e sementes de frutos. Como essas aves não estabelecem territórios, movimentam-se através de mosaicos de vegetação no sentido de utilizar recursos alimentares, produzidos massivamente, à medida que se tornam disponíveis. Neste estudo, nós examinamos a utilização de uma mata ciliar, no Pantanal Sul (Brasil), por uma comunidade de psitacídeos, constituída por um gradiente de formas que incluiu desde o pequeno Brotogeris chiriri até a grande Ara chloroptera. Os recursos vegetais, importantes para os psitacídeos, foram produzidos massivamente durante a estação chuvosa (frutos carnosos), subseqüentemente durante as cheias anuais (também frutos carnosos) e, finalmente, na estação seca (flores). Tanto as pequenas quanto as grandes espécies consumiram tais frutos, no entanto os periquitos utilizaram predominantemente a polpa, enquanto as espécies maiores consumiram em proporções similares a polpa e as sementes. Durante a estação seca os periquitos utilizaram extraordinariamente néctar das flores, sobretudo produzido por Inga vera, que anualmente floresceu massivamente ao final da estação 
seca, período mais rigoroso do ano. Dentre as espécies maiores, apenas Propyrrhura auricollis utilizou substancialmente néctar. A intensa produção de frutos, tipicamente dispersos por peixes ou pela água durante a cheia anual, foi amplamente utilizada pelos psitacídeos. Portanto, ao contrário dos padrões de frutificação da maioria das matas secas neotropicais, a ocorrência de um pico de frutificação durante as cheias emerge como um evento marcante de disponibilidade de frutos, num período (transição da estação úmida para a seca) em que tipicamente tendem a declinar. Nesse sentido, a peculiar produção massiva de flores e frutos, nessa mata ciliar, potencialmente contribui para manutenção das grandes populações de psitacídeos, ainda presentes, no Pantanal Sul.

Palavras-chave: Psittacidae, papagaios, ecologia alimentar, mata ciliar, fenologia, Pantanal.

\section{INTRODUCTION}

Among the Neotropical bird groups, Psittacidae is prominent both in species and number of individuals, which form a substantial proportion of the bird biomass in forest canopies (Terborgh et al., 1990). As pre-dispersal seed predators (Janzen, 1981; Coates-Estrada et al., 1993), their ecological role may significantly influence tree richness in Neotropical forest (Dirzo \& Miranda, 1990). Recently, some parrot species have been identified as possible tree-species pollinators, however few studies have focused on parrotflower relationships (but see Vicentini \& Fischer, 1999; Cotton, 2001; Ragusa-Netto, 2002). Also, studies have also shown that these parrots exhibit low reproductive rates, usually nest in tree holes, are long-lived, have no all-purpose territories, and forage over large areas of various types so as to exploit food resources that are both plentiful and ephemeral (Renton, 2001; Ragusa-Netto, 2004; 2005). Due to their mobility and dietary flexibility, parrots can adjust to the marked seasonality of food resource production in forest canopies (Renton, 2001). For example, even though Neotropical parrots customarily forage on fruits and seeds, flower consumption may be vital when fruit production declines, mainly during the dry season (Galetti, 1993; Ragusa-Netto, 2004, 2005). Unlike some other species, Neotropical parrots seldom forage on arthropods (del Hoyo et al., 1997; Renton, 2001).

The Pantanal (Brazil), an extensive flood plain $\left(140,000 \mathrm{~km}^{2}\right)$ in central South America, contains semi-arid vegetation including grasslands, savannas, and patches of dry forests, in addition to dense gallery forests (Pott \& Pott, 1994). The gallery forests usually exhibit less pronounced leaf loss, and are rich in plant species, among them trees that yield fleshy fruits (Funch et al., 2002). As many parrot species are often associated with watercourses (Forshaw, 1989; del Hoyo et al., 1997), plant food resource use may be among the reasons.

In this study we examine the patterns of flower and fruit production, as well as plant food resource exploitation by a parrot community at the Miranda River gallery forest in the southern Pantanal. At least seven parrot species are often present in the gallery forests in this region, ranging from parakeets (Brotogeris chiriri) to macaws (Ara chloroptera), whose food requirements are poorly known and may be very different (del Hoyo et al., 1997; Sick, 1997).

\section{METHODS}

\section{Study area}

This study was carried out between April 2000 and March 2002 in the southern Pantanal flood plain at the Miranda River gallery forest $\left(19^{\circ} 34^{\prime} \mathrm{S}, 57^{\circ}\right.$ $01^{\prime} \mathrm{W}$, elevation $\pm 100 \mathrm{~m}$ ), an area used for studies of the Pantanal by the Universidade Federal de Mato Grosso do Sul (UFMS) at Corumbá, Mato Grosso do Sul State. Area vegetation forms a mosaic of palm savanna (Copernicia alba), tecoma savanna (Tabebuia aurea), patches of deciduous forest interspersed with open grassy areas, and the dense gallery forest of the Miranda River. This forest is 50-200 m wide, with an 8-13 $\mathbf{~ m}$ canopy, within which emergent trees may reach up to $17 \mathrm{~m}$. From July to September many tree species drop their leaves, although some abundant evergreen species such as Inga vera and Ocotea diospyrifolia are part of an evident semi-deciduous pattern. Annual rainfall is around $1000 \mathrm{~mm}$, most of which occurs from November to March (rainy season). In 
this period temperatures average $27^{\circ} \mathrm{C}$, while in the dry season (April-October) the average is $20^{\circ} \mathrm{C}$; in the coldest months (June-July) frosts may occur. In this area of the Pantanal, inundation pulses typically occur from January to March. During floods, water level in gallery forest can reach $1.5 \mathrm{~m}$ (Fig. 1), but both seasonal length and climatic conditions may vary greatly (source: airport meteorological service, Corumbá, MS).

\section{Flower and fruit production}

To sample flower and fruit production and its use by parrots, phenology transects (a 5-km total) were marked in four tracts (400-800 m apart) of the gallery forest. In this habitat, topography and drainage are not uniform and neither is the flooding effect. Consequently, and also because of the patchy distribution of tree species (Oliveira-Filho et al., 1990; Oliveira-Filho et al., 1994), we (A. Fecchio assisted J. Ragusa-Netto in data collection and analyses) randomly positioned continuous $300 \mathrm{~m}$ transect segments parallel to the water course, whose distances from the river edge were: $5 \mathrm{~m}$, $35 \mathrm{~m}, 65 \mathrm{~m}$, and $95 \mathrm{~m}$. Along these trails, 370 trees were numbered with aluminum tags. Trees were selected when located within a $2.0 \mathrm{~m}$ margin on either side of the trails and presenting a diameter at breast height (DBH) equal to or greater than $30 \mathrm{~cm}$. As parrots typically forage in canopies, this was to ensure inclusion of canopy and emergent trees in the samplings. In addition, trees were selected only if at least $80 \%$ of their crown were visible from the forest floor.

Random samplings included 29 tree species, whose use by parrots was unknown. Using $8 \times 40$ binoculars, we monitored individual crowns monthly (between days 5 and 10, from April 2000 to March 2002) for the presence of flowers and fruits. Flower abundance, and ripe and unripe fruits were recorded and ranked on a relative scale ranging from total absence (0) to full-crown capacity (4) of a given phenophase (Fournier, 1974). Thus, the monthly resource abundance index in a given phenophase represented the sum of all abundance scores.

Tree species were identified by comparing them with samples in the herbarium of the Universidade Federal do Mato Grosso do Sul (Corumbá campus) and following Pott \& Pott (1994). Analysis of dispersal syndromes exceeded the scope of this study, hence fruits of tree species were classified only by presence of edible fleshy parts, rather than dispersal features (zoochory, autochory, and anemochory). Thus, trees whose diaspores included pulp or aril were classified as species bearing fleshy fruit, and those with dry mesocarps and bearing dry fruit were classified accordingly.

\section{Parrot food-resource use}

In order to sample food items exploited by parrots, we monitored the same trails used to sample resource abundance. We walked along the trails for $30 \mathrm{~h}$ monthly, from $6 \mathrm{~h}$ to $11 \mathrm{~h}$ and from $15 \mathrm{~h}$ to $18 \mathrm{~h}$, when parrots were usually active. When a sighting occurred, we recorded: a) tree species; b) food resource (flower or fruit); c) part eaten (petal, nectar, pulp, or seed); d) species and number of parrots foraging, irrespective of time spent foraging and amount of food ingested; and e) time and date.

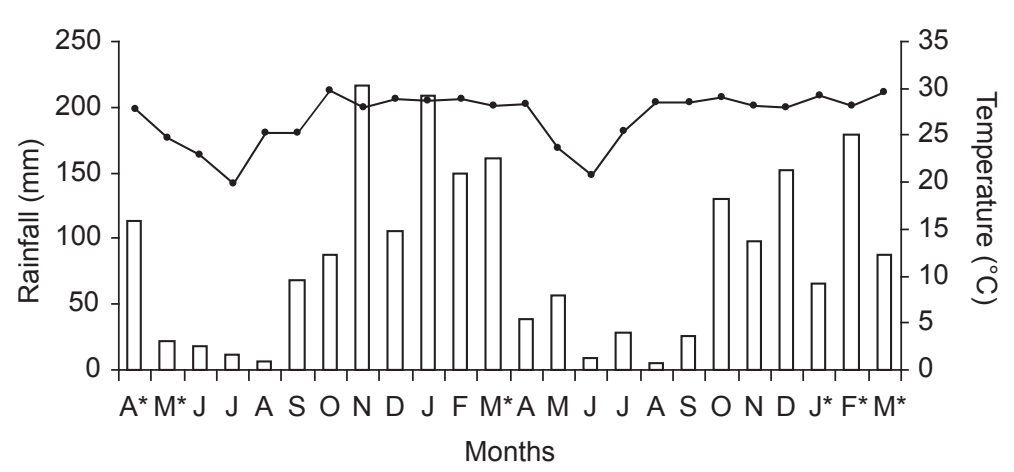

Fig. 1 - Monthly rainfall (columns), and average temperature (line) from April 2000 to March 2002 in the southern Pantanal. Asterisk denotes flood period. 
As the feeding records were used to evaluate the diversity of food resources used in relation to their availability, we used only the initial observations to ensure independence among foraging samples, which is specially valid in the case of Neotropical parrots, because most of which are opportunistic feeders and include in their diet food items that are a relatively large, but only seasonally available part of the food biomass. In addition, it can be assumed that the birds are equally likely to be seen feeding on any abundantly available resource (Hejl et al., 1990).

\section{RESULTS}

\section{Flower and fruit production}

The 29 tree species recorded in the phenology transects belonged to 18 families. Most tree species $(66 \%)$ and individuals $(80 \%, n=370$ trees) produced fleshy fruits, while only 10 species and 74 individuals produced dry fruits. Among the most common species were Inga vera (66 trees), Ocotea diospyrifolia (62), Vitex cymosa (43), Tabebuia heptaphylla (36), Cecropia pachystachya, and Genipa americana (both 24 trees). Flower production peaked twice annually, first in the middle of the dry season, mainly because of Tabebuia heptaphylla and Ocotea diospyrifolia, and again and markedly so during the transition from the dry to the wet season (Figs. 1,2). This second flower production peak was mainly due to Vitex cymosa, Cecropia pachystachya, and Genipa americana, in addition to the abundant Inga vera, whose exuberant flowering lasted for two months (Table 1, Fig. 2). The pronounced flowering of $I$. vera accounted for $45 \%$ of the peak in October 2000 and 62\% in September 2001. A third minor peak resulted principally from flowering in species such as Banara arguta and Sapium obovatum that are often exposed to floods for longer periods. However, flowering in these species was more plentiful during February 2001 (late wet season) than in the same period in 2002 (Fig. 2).

Fruiting was seasonal and also exhibited two major annual peaks. In the middle of the wet season (December-February; for unripe fruits, the peaks occurred a month earlier) a very pronounced fruiting peak was recorded, while another fruiting peak occurred in the transition from the wet to
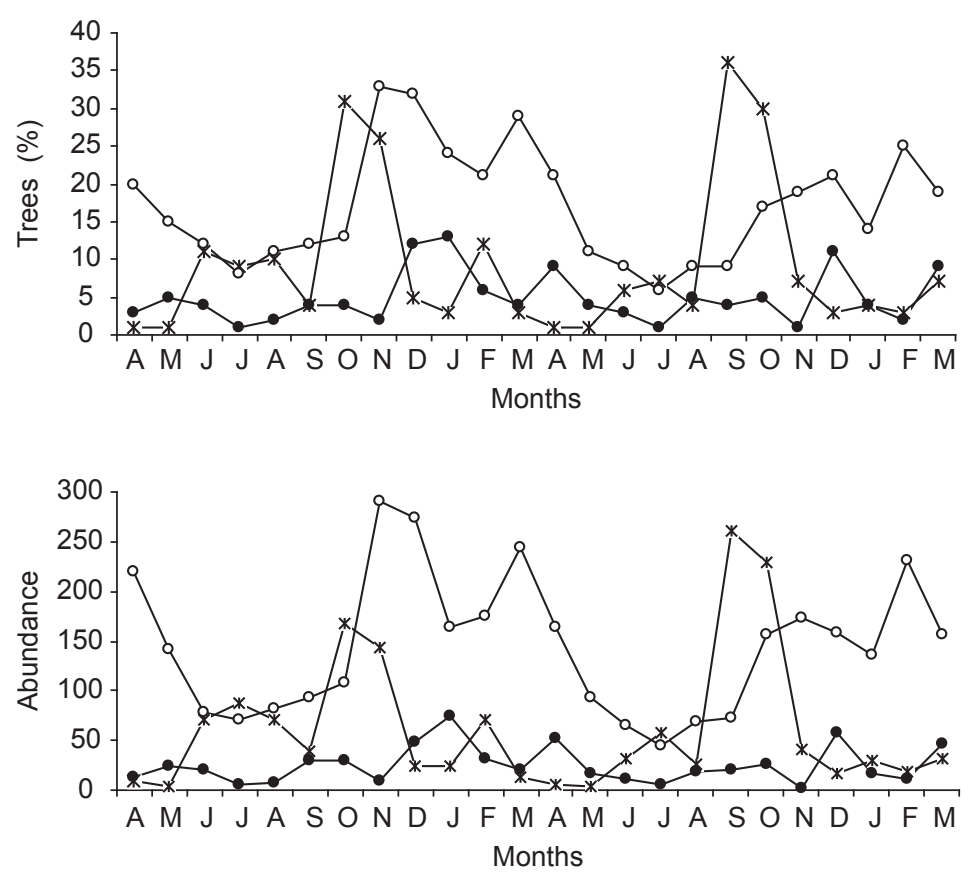

Fig. 2 - Percentage of flowered trees (asterisk, $\mathrm{N}=370$ ), trees bearing immature (open circle) and mature fruits (full circle), as well as the abundance (sum of scores; see methods) of these resources from April 2000 to March 2002 in the Miranda River gallery forest. 
TABLE 1

Availability of flowers (Light grey) and fruits (dark grey) used by parrots in the Miranda River gallery forest.

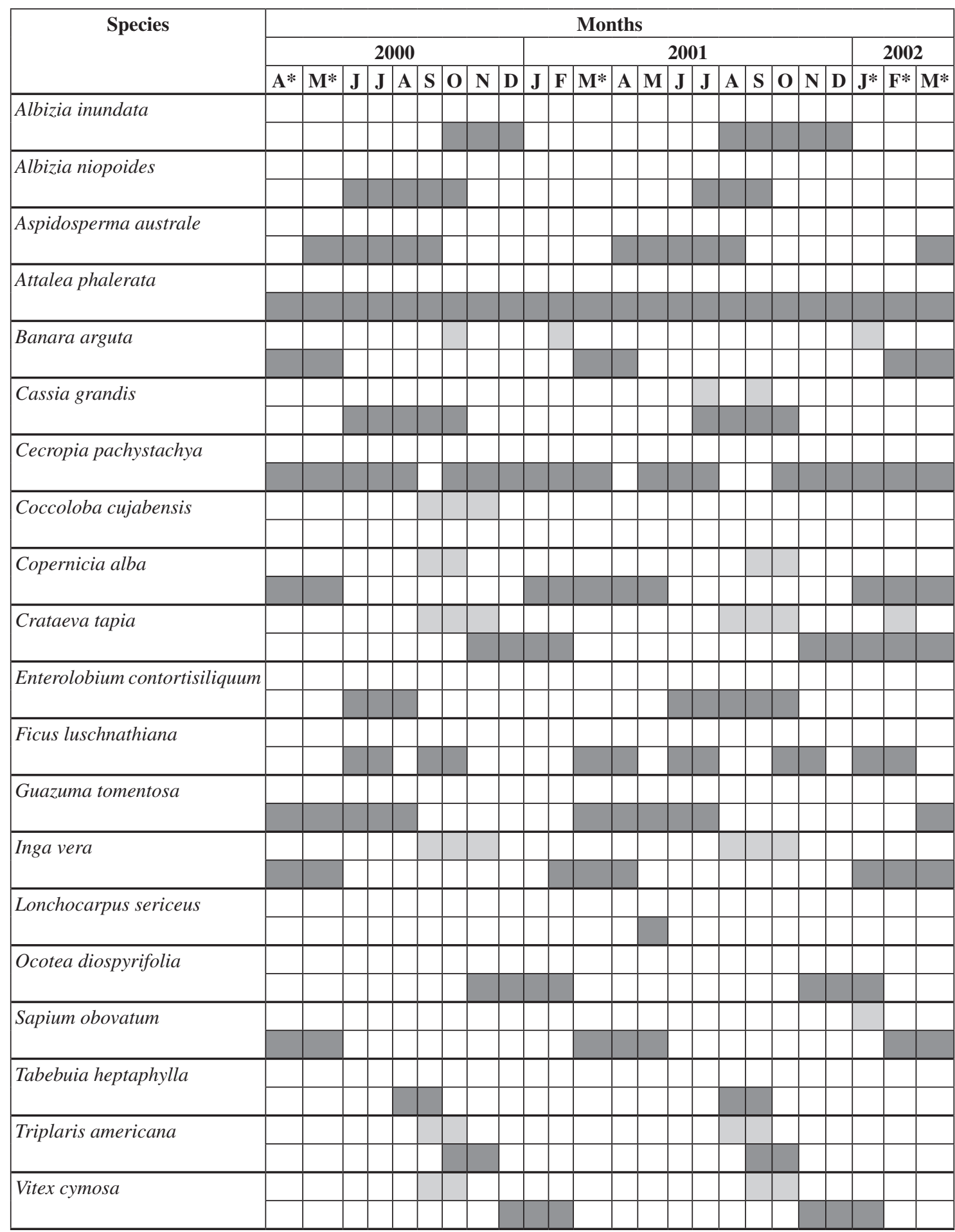

*flood period. 
the dry season (March-May; Fig. 2). The fruiting peak in the middle of the wet season (December 2000 to February 2001) represented mainly Vitex cymosa, Ocotea diospyrifolia, and Cecropia pachystachya. These species bore large quantities of fruit (Fig. 2); however, in the following wet season Ocotea diospyrifolia produced no fruits, whereas Cecropia pachystachya bore fruits later. Thus, the large fruit crop of Vitex cymosa was the major contributor to the fruiting peak in this period (Fig. 2). The production peak in the transition from the wet to the dry season resulted from fruiting of Banara arguta, Sapium obovatum, Crataeva tapia, Copernicia alba, and Inga vera. The latter, despite abundant flowering, generally bore small fruit loads. On the other hand, Banara arguta and Sapium obovatum bore very large amounts of fruit that accounted for most of this fruiting peak. Fruits of all these species matured during floods (Fig. 2, Table 1).

\section{Parrot food resource use}

Parrots foraged at 29 tree species from 18 families, making a total of 785 feeding records (Table 2). They extensively exploited tree species that produced very large and ephemeral crops such as Inga vera (flowers; dry season), Vitex cymosa (fruit; rains), Sapium obovatum (fruit; floods), and Attalea phalerata (fruit; year-round) (Tables 1, 2). During the rainy season, larger species (mainly Amazona aestiva and Propyrrhura auricollis) foraged on $V$. cymosa and Ocotea diospyrifolia fruits. On the other hand, parakeets seldom used these fruits, while extensively foraging for Cecropia pachystachya catkins, of which they used the pulp and seeds (Table 2). Although parakeets extensively foraged on this species during the rains, they (and principally among them - Myiopsitta monachus) also foraged on it whenever available (Tables 1, 2).

During the annual floods some fruits were heavily used by parrots. Amazona aestiva and Aratinga acuticaudata foraged extensively on Sapium obovatum seeds. This item. which figured among the major resources of A. aestiva by whom it was consumed only in the evening, was by far the most important for A. acuticaudata, large flocks of which consumed these seeds during midmorning (Table 2). Other important food resources during the floods were Banara arguta, Copernicia alba, and Inga vera fruits. While B. arguta was among the major foods of M. monachus and Nandayus nenday, C. alba was significant for Brotogeris chiriri and N. nenday (Table 2). From I. vera parrots mostly consumed the aril, which is vital both for larger (A. aestiva, and P. auricollis), and smaller species (A. acuticaudata, B. chiriri, and $N$. nenday (Table 2).

In the dry season nectar was a major food source. For almost all parakeets this was the most exploited resource, although it was seldom consumed by larger parrot species, with the exception of $P$. auricollis (Table 2). During the late dry season $I$. vera nectar was particularly crucial, since it comprised the bulk of parakeet diets and amounted to over $70 \%$ of the feeding recorded for abundant species such as B. chiriri, $N$. nenday, and M. monachus. Parrots mainly used seeds from dry fruits and fruit pulp of Attalea phalerata, which was heavily foraged on by parakeets. Consumption of this fruit occurred almost year-round, in keeping with its production (Tables 1,2).

\section{DISCUSSION}

\section{Flower and fruit production}

As part of a vegetation mosaic, the Miranda River gallery forest's major feature is a preponderance of tree species with fleshy fruits, probably explains this forest's importance within the highly seasonal Pantanal. The rains and floods made fleshy fruits available during a substantialy longer period than that of marked seasonal forests in which the fruiting pattern is strongly influenced only by rains (Bullock \& Solis-Magallanes, 1990). Also, when fruit production declined, flowering was highest due to numerous species such as Inga vera that flowered abundantly, making this forest also an extraordinarily rich source of nectar during periods of scarcity.

In Neotropical dry forests, massive flowering usually occurs between the late dry and the early wet season, which is followed closely by fruit production (Frankie et al., 1974; Bullock \& SolisMagallanes, 1990). At the Miranda River gallery forest, the major annual flowering peak fits this pattern, and the local tree species primarily produce fleshy fruits during the rainy season. Annually, pronounced flowering occurs when the river level 
TABLE 2

Plant species and respective item used by parrots at the Miranda river gallery forest. (Total feeding records per parrot species: Amazona aestiva-118, Ara chloroptera-2, Aratinga aurea-7, Aratinga acuticaudata-37, Brotogeris chiriri-131, Myiopsitta monachus-347, Nandayus nenday-106, Propyrrhura auricollis-31, Pionus maximiliani-6).

\begin{tabular}{|c|c|c|c|c|c|}
\hline Plant taxa & Parrot species & $\begin{array}{c}\text { Feeding records } \\
(\%)\end{array}$ & Item aten* & Month & $\begin{array}{c}\text { Foraging } \\
\text { individuals }\end{array}$ \\
\hline \multicolumn{6}{|l|}{ Annonaceae } \\
\hline Rollinia emarginata & M. monachus & 0.3 & $\mathrm{a}$ & Jan. & 2 \\
\hline \multicolumn{6}{|l|}{ Apocynaceae } \\
\hline Aspidosperma australe & A. aestiva & 7.0 & $\mathrm{~s}$ & Apr.-May & 16 \\
\hline \multicolumn{6}{|l|}{ Bignoniaceae } \\
\hline Tabebuia aurea & M. monachus & 0.3 & $\mathrm{n}$ & Sept. & 7 \\
\hline \multirow[t]{5}{*}{ Tabebuia heptaphylla } & A. aestiva & 6.0 & $\mathrm{f}$ & Jul.-Aug. & 16 \\
\hline & B. chiriri & 0.8 & $\mathrm{n}$ & Aug. & 3 \\
\hline & M. monachus & 1.4 & $\mathrm{n}$ & Jul.-Aug. & 19 \\
\hline & N. nenday & 3.0 & $\mathrm{n}$ & Jul.-Aug. & 26 \\
\hline & P. maximiliani & 16.6 & $\mathrm{f}$ & Sep. & 4 \\
\hline \multicolumn{6}{|l|}{ Caparidaceae } \\
\hline \multirow[t]{3}{*}{ Crataeva tapia } & A. aestiva & 1.0 & $\mathrm{p}, \mathrm{s}$ & Feb. & 2 \\
\hline & B. chiriri & 0.8 & $\mathrm{p}, \mathrm{s}$ & Feb. & 2 \\
\hline & N. nenday & 2.0 & $\mathrm{n}$ & Aug. & 10 \\
\hline \multicolumn{6}{|l|}{ Cecropiaceae } \\
\hline \multirow[t]{4}{*}{ Cecropia pachystachya } & A. aestiva & 2.0 & $\mathrm{p}, \mathrm{s}$ & Jan. & 4 \\
\hline & B. chiriri & 16.8 & $\mathrm{p}, \mathrm{s}$ & Dec.-Mar. & 61 \\
\hline & M. monachus & 26.2 & $\mathrm{p}, \mathrm{s}$ & Dec.-Jun.; Sept.-Oct. & 256 \\
\hline & N. nenday & 6.0 & $\mathrm{p}, \mathrm{s}$ & Jan.-Feb.; Apr. & 12 \\
\hline \multicolumn{6}{|l|}{ Combretaceae } \\
\hline Combretum lanceolatum & M. monachus & 0.3 & $\mathrm{n}$ & Jun. & 4 \\
\hline \multicolumn{6}{|l|}{ Euphorbiaceae } \\
\hline \multirow[t]{3}{*}{ Sapium obovatum } & A. aestiva & 16.0 & $\mathrm{~s}$ & Mar.-May & 122 \\
\hline & A. acuticaudata & 86.0 & $\mathrm{~s}$ & Mar.-Apr. & 258 \\
\hline & M. monachus & 1.2 & $\mathrm{a}, \mathrm{s}$ & Apr.-May & 14 \\
\hline \multicolumn{6}{|l|}{ Flacourtiaceae } \\
\hline \multirow[t]{4}{*}{ Banara arguta } & A. aestiva & 1.0 & $\mathrm{p}, \mathrm{s}$ & Apr. & 2 \\
\hline & B. chiriri & 1.6 & $\mathrm{p}, \mathrm{s}$ & Apr. & 4 \\
\hline & M. monachus & 12.0 & $\mathrm{p}, \mathrm{s}$ & Mar.-May & 156 \\
\hline & N. nenday & 7.0 & $\mathrm{p}, \mathrm{s}$ & Apr.-May & 42 \\
\hline \multicolumn{6}{|l|}{ Lauraceae } \\
\hline \multirow[t]{3}{*}{ Ocotea diospyrifolia } & A. aestiva & 9.0 & $\mathrm{p}$ & Jan.-Feb. & 35 \\
\hline & M. monachus & 0.6 & $\mathrm{p}$ & Jan. & 3 \\
\hline & N. nenday & 2.0 & $\mathrm{p}$ & Jan. & 2 \\
\hline \multicolumn{6}{|l|}{ Leguminosae } \\
\hline Albizia inundata & A. aestiva & 1.0 & $\mathrm{~s}$ & Nov. & 4 \\
\hline \multirow[t]{2}{*}{ Albizia niopoides } & A. aestiva & 1.0 & $\mathrm{~s}$ & Aug & 3 \\
\hline & P. maximiliani & 16.6 & $\mathrm{~s}$ & Aug. & 2 \\
\hline Bauhinia sp. & M. monachus & 0.6 & $\mathrm{f}$ & Oct. & 10 \\
\hline Cassia grandis & A. chloroptera & 50.0 & $\mathrm{~s}$ & Apr. & 2 \\
\hline
\end{tabular}


TABLE 2

Contined...

\begin{tabular}{|c|c|c|c|c|c|}
\hline Plant taxa & Parrot species & $\begin{array}{c}\text { Feeding records } \\
(\%)\end{array}$ & Item aten* & Month & $\begin{array}{c}\text { Foraging } \\
\text { individuals } \\
\end{array}$ \\
\hline \multirow{2}{*}{$\begin{array}{l}\text { Enterolobium } \\
\text { contortisiliquum }\end{array}$} & A. aestiva & 1.0 & $\mathrm{~s}$ & Aug.-Sept. & 3 \\
\hline & P. auricollis & 3.2 & $\mathrm{~s}$ & Oct. & 2 \\
\hline \multirow[t]{2}{*}{ Erythrina fusca } & A. aestiva & 4.0 & $\mathrm{f}$ & Sept. & 10 \\
\hline & B. chiriri & 0.8 & $\mathrm{n}$ & Sept. & 1 \\
\hline \multirow[t]{12}{*}{ Inga vera } & \multirow[t]{2}{*}{ A. aestiva } & 8.0 & $\mathrm{a}, \mathrm{s}$ & Mar.-Apr. & 20 \\
\hline & & 1.0 & $\mathrm{n}$ & Oct. & \\
\hline & A. aurea & 71.5 & $\mathrm{n}$ & Sept.-Oct. & 13 \\
\hline & A. acuticaudata & 14.0 & $\mathrm{a}, \mathrm{s}$ & & 49 \\
\hline & \multirow[t]{2}{*}{ B. chiriri } & 12.2 & $\mathrm{a}$ & Feb.- Apr. & 49 \\
\hline & & 29.0 & $\mathrm{n}$ & Aug.-Nov. & 188 \\
\hline & \multirow[t]{2}{*}{ M. monachus } & 1.2 & $\mathrm{a}$ & Apr, May & 17 \\
\hline & & 35 & $\mathrm{n}$ & \begin{tabular}{|l} 
Oct.-Nov.; \\
Aug.- ept.
\end{tabular} & 577 \\
\hline & \multirow[t]{2}{*}{ N. nenday } & 6.0 & $\mathrm{a}$ & Mar.-May & 47 \\
\hline & & 58.0 & $\mathrm{n}$ & Sept.-Nov. & 674 \\
\hline & \multirow[t]{2}{*}{ P. auricollis } & 10.0 & $\mathrm{a}, \mathrm{s}$ & Mar., May & 9 \\
\hline & & 16.0 & $\mathrm{n}$ & Oct., Sept. & 22 \\
\hline Lonchocarpus sericeus & B. chiriri & 0.8 & $\mathrm{n}$ & Mar. & 10 \\
\hline \multicolumn{6}{|l|}{ Malpighiaceae } \\
\hline Byrsonima orbignyana & P. auricollis & 3.2 & $\mathrm{~s}$ & May & 2 \\
\hline \multicolumn{6}{|l|}{ Moraceae } \\
\hline \multirow[t]{4}{*}{ Ficus luschnathiana } & A. aestiva & 3.0 & $\mathrm{p}, \mathrm{s}$ & Mar., Oct. & 10 \\
\hline & B. chiriri & 10.7 & $\mathrm{p}, \mathrm{s}$ & Mar., Jun., Oct., Dec. & 64 \\
\hline & M. monachus & 1.7 & $\mathrm{p}, \mathrm{s}$ & Oct., Sept. & 21 \\
\hline & P. auricollis & 6.5 & $\mathrm{p}, \mathrm{s}$ & Mar., Oct. & 4 \\
\hline \multirow[t]{2}{*}{ Ficus pertusa } & B. chiriri & 1.6 & $\mathrm{p}, \mathrm{s}$ & Nov. & 20 \\
\hline & M. monachus & 0.6 & $\mathrm{p}, \mathrm{s}$ & Nov. & 12 \\
\hline \multicolumn{6}{|l|}{ Palmae } \\
\hline \multirow[t]{4}{*}{ Copernicia alba } & B. chiriri & 8.4 & $\mathrm{p}$ & Apr., May & 26 \\
\hline & M. monachus & 1.4 & $\mathrm{p}$ & May & 19 \\
\hline & N. nenday & 5.0 & $\mathrm{p}$ & Apr., May & 14 \\
\hline & P. auricollis & 3.2 & $\mathrm{~s}$ & May & 2 \\
\hline \multirow[t]{6}{*}{ Attalea phalerata } & A. aestiva & 10.0 & $\mathrm{p}$ & Jan., Apr., Aug., Jul. & 25 \\
\hline & A. chloroptera & 50.0 & $\mathrm{p}$ & May & 2 \\
\hline & B. chiriri & 10.0 & $\mathrm{p}$ & Apr.-Oct.; Dec.-Feb. & 25 \\
\hline & M. monachus & 12.0 & $\mathrm{p}$ & Dec.-Feb., May-Set. & 152 \\
\hline & N. nenday & 9.0 & $\mathrm{p}$ & Jan.-Jul.; Sept.-Dec. & 49 \\
\hline & P. maximiliani & 50.0 & $\mathrm{p}$ & Jul. & 7 \\
\hline \multicolumn{6}{|l|}{ Polygonaceae } \\
\hline Coccoloba cujabensis & M. monachus & 0.3 & $\mathrm{p}, \mathrm{s}$ & Oct. & 4 \\
\hline \multirow[t]{2}{*}{ Triplaris americana } & M. monachus & 3.5 & $\mathrm{~s}$ & Sept. & 47 \\
\hline & N. nenday & 1.0 & $\mathrm{~s}$ & Sept. & 6 \\
\hline
\end{tabular}


TABLE 2

Contined...

\begin{tabular}{|c|c|c|c|c|c|}
\hline Plant taxa & Parrot species & $\begin{array}{c}\text { Feeding records } \\
(\%)\end{array}$ & Item aten* & Month & $\begin{array}{c}\text { Foraging } \\
\text { individuals }\end{array}$ \\
\hline \multirow[t]{2}{*}{ Guazuma tomentosa } & A. aestiva & 1.0 & $\mathrm{~s}$ & Jan. & 2 \\
\hline & P. auricollis & 13.0 & $\mathrm{~s}$ & Aug. & 11 \\
\hline \multicolumn{6}{|l|}{ Ulmaceae } \\
\hline Trema micrantha & A. aurea & 14.3 & $\mathrm{p}, \mathrm{s}$ & Nov. & 3 \\
\hline \multicolumn{6}{|l|}{ Verbenaceae } \\
\hline \multirow[t]{9}{*}{ Vitex cymosa } & A. aestiva & 29.0 & $\mathrm{p}$ & Dec., Jan. & 132 \\
\hline & A. aurea & 14.3 & $\mathrm{p}$ & Dec. & 4 \\
\hline & \multirow[t]{2}{*}{ B. chiriri } & 1.5 & $\mathrm{f}$ & Oct. & 3 \\
\hline & & 3.0 & $\mathrm{p}$ & Dec., Jan. & 40 \\
\hline & M. monachus & 1.4 & $\mathrm{p}$ & Dec., Jan. & 7 \\
\hline & \multirow[t]{2}{*}{ N. nenday } & 1.0 & $\mathrm{f}$ & Oct. & 3 \\
\hline & & 1.0 & $\mathrm{p}$ & Dec. & 1 \\
\hline & P. auricollis & 45.0 & $\mathrm{p}, \mathrm{s}$ & Nov., Dec. & 37 \\
\hline & P. maximiliani & 16.6 & $\mathrm{p}, \mathrm{s}$ & Dec. & 3 \\
\hline \multicolumn{6}{|l|}{ Viscaceae } \\
\hline \multirow[t]{2}{*}{ Phoradendron affine } & M. monachus & 0.3 & $\mathrm{p}, \mathrm{s}$ & May & 4 \\
\hline & B. chiriri & 2.3 & $\mathrm{p}, \mathrm{s}$ & May & 16 \\
\hline
\end{tabular}

* Item eaten: a-aril, f-flowers, n-nectar, p-pulp, s-seeds.

is lowest (pers. obs.); therefore, dry conditions could contribute to triggering this phenophase, as was noticed in a gallery forest studied elsewhere (Kinnaird, 1992).

It is widely accepted that trees flower synchronously, which attracts pollinators and enhances pollen flow and/or prevents substantial flower loss to nectar robbers (van Schaik et al., 1993). This may be the case in the Miranda River gallery forest, in which few abundant species contributed most to the flowering pattern.

The annual fruiting peaks presumably resulted from the influence of separate environmental factors on two groups of tree species. The pronounced fruiting peak in the middle of the wet season followed a typical fruiting pattern based on rainfall seasonality, as has been suggested for other neotropical semi-deciduous forests (Frankie et al., 1974; Bullock \& Solis-Magallanes, 1990; Peres, 1994). The predominance of fleshy fruit production during the rainy season has been found in markedly seasonal habitats, e. g., dry forests (Griz \& Machado, 2001; Renton, 2001), and apparently is usual for gallery forests within dry areas (Funch et al., 2002). Fruiting during the rainy season favors seed germination as well as rapid seedling growth, and limits seedling mortality that occurs during the prolonged dry season of markedly seasonal forests (van Schaik et al., 1993).

The other fruiting peak, which was more impressive when unripe fruit production was analyzed (Fig. 2), resulted from species exposed to floods over longer periods (pers. obs.). The fruits of these species matured simultaneously with inundations, and released a large number of diaspores into the water. This fruiting pattern resembles those found in the Amazonian flood plain, in which the fruiting peak of trees coincides with forest inundation, and diaspores are adapted for water and fish dispersal (Kubitzki \& Ziburski, 1994). Thus, the dynamic fruit production in the Miranda River gallery forest evidenced the unique features of flood plains, whose cycles are strongly influenced by water levels.

\section{Parrot food-resource use}

In spite of the importance of parrots in Neotropical areas, their feeding ecology as communities has been little studied. In South America, research was carried out both in Amazonia 
(Roth, 1984) and in Atlantic forest (Pizo et al., 1995; Galetti, 1997; Simão et al., 1997), while in the drier areas studies of this kind are practically nonexistent. However, similarly to the parrots studied elsewhere, each species in the Miranda River gallery forest exploited specific abundant resources available during short periods, during which smaller species foraged mostly on nectar and fruit pulp, while - as expected - medium to large species foraged more often on seeds.

In the Miranda River gallery forest, the fruits available during floods, which are used by many fish species (Pott \& Pott, 1994), comprised a substantial proportion of resources exploited by parrots. Particularly, Banara arguta, Sapium obovatum, Copernicia alba, and Inga vera were simultaneously used by at least two, if not by most of the parrot species present (I. Vera; Table 2). Annual floods typically occur from January to April (the transition from the wet to the dry season), in the latter part of which fruit production in dry forests tends to decline (van Schaik et al., 1993). Therefore, intense fruit production during floods constitutes an extra episode, uncommon in markedly seasonal forests, of food resource availability (Bullock \& Solis-Magallanes, 1990; Griz \& Machado, 2001). Apparently, the gallery forests in this area of the Pantanal are highly fruit productive in comparison to neighboring dry habitats, in a pattern resembling that of the Amazonian varzea (Peres, 1994).

During the dry season, parrots foraged among few fruit species, notably Cecropia pachystachya, which bears fruit up to thrice yearly, and Attalea phalerata whose fruiting is aseasonal. Thus, both fruits were being produced most of the time.

The trees of Cecropia pachystachya were clumped, presumably due to tree-fall gap colonization, and large amounts of fruits were available at such sites. Conversely, scattered in the forest was A. phalerata, and palms are recognized has being of vital importance to frugivores during critical periods when fruit production declines (Terborgh, 1986). Fruits of this species are extensively used, mainly from the middle to the late dry season, by most parrot species in the Pantanal, and also are a major food item for Anodorhychus hyacinthinus (N. Guedes, pers. com.).

Parrots also extensively foraged on flowers during the dry season. Species such Tabebuia heptaphylla and Inga vera, besides being plentiful, annually produced abundant flower crops. Flowers from I. vera stood out among the major food resources of most parrot species, mainly for parakeets, which foraged on nectar primarily in the late dry season. However, even for the large Propyrrhura auricollis nectar was an important food resource.

Nectar has been assumed to be a useful substitute when fruit is scarce (Terborgh, 1986; Terborgh \& Stern, 1987; Gryjl et al., 1990; Ferrari \& Strier, 1992), and among them the sucrose-rich Inga vera nectar is similar to that of hummingbirdpollinated flowers, hence suitable for animals with high metabolism (Stiles \& Freeman, 1993). Therefore, the plentiful supply of flowers per tree makes this species a rich food resource during prolonged dry seasons. The importance of I. vera nectar was also surmised because in the neighboring patches of deciduous forest, figs (mainly Ficus luschnatiana and F. pertusa) and palms (A. phalerata), are common and produce fruit asynchronously. Therefore, fruits of these trees, which are scattered, is sometimes available at the same time as I. vera nectar (Ragusa-Netto, unpublished results). If $I$. vera nectar were not highly rewarding nutritionally, lower consumption by parrots would be expected.

In spite of plentiful fruit availability during the rainy season, parrots foraged intensively only in Ocotea diospyrifolia, Vitex cymosa, and Cecropia pachystachya. In that period, these abundant species -. especially $V$. cymosa - bore very large fruit crops and were the highest fruit producers.

Although the usually lipid-rich fruit of the family Lauraceae, the lipid-poor fruit of Verbenaceae (Wheelwright et al., 1984; Stiles, 1993), and particularly the fruit of $O$. diospyrifolia and V. cymosa are all uncommon in the diet of parrots studied elsewhere in South America (Pizo et al., 1995; Galetti, 1997; Simão et al., 1997), parrots from the Miranda River gallery forest more often preferred fruit pulp of $O$. diospyrifolia and $V$. cymosa to presumably more nutritive seeds. But since the nutritive value of these fruit pulps was not assessed, it is unclear if parrots foraged intensely on these resources due to their abundance, quality, or both.

Unlike larger species, parakeets made little use of $O$. diospyrifolia and V. cymosa, so that during the rainy season, their most common food source was Cecropia pachystachya fruitlets. In addition, 
although the nutritional quality of Cecropia catkin pulp is low, this species may provide additional nutrients to parakeets consuming its seeds, which regardless of the size were always ingested, even by smaller parrots.

All parrot species that foraged in the Miranda River gallery forest are still abundant in the Pantanal and present generalist feeding habits (del Hoyo et al., 1997; Sick, 1997). This study evidenced the high dietary adaptability of these birds, mostly in their intensive flower foraging during harsh periods, an uncommon pattern of dietary shift among Neotropical parrots about which detailed data on year-round diet are available (Roth, 1984; Pizo et al., 1995; Galetti, 1997; Simão et al., 1997).

Many tree species whose flowers or fruits were extensively exploited by parrots are common in light gaps (Attalea, Cecropia, and Ficus) and in second-growth stretches (Inga, Vitex, Sapium, and Tabebuia; Lorenzi, 1994, 1998), in both of which fruit production is higher when compared to that of primary forests (Levey, 1988). Hence, the abundance of food resources these species provide, mainly during harsh periods, suggests the importance of gallery forests to the continued existence of this parrot community in the highly seasonal Pantanal.

Acknowledgments - We are grateful to Gesner Batista Ramos, Jacqueline Vasquez, André Silveira, and Cláudia Bitencourt for field assistance. Edílson Silva, Rosemar Santos, Rosana Costa, and Josefa de Oliveira provided logistical support in the Base de Estudos do Pantanal of the Universidade Federal de Mato Grosso do Sul (BEP/UFMS). I thank Rosilene Rodrigues-Silva for assisting in identifying some plant species. The comments of an anonimous reviwer improved the manuscript. Financial support was provided by FUNDECT, CNPq (which also awarded Alan Fecchio a PIBIC-grant ), and PROPP/UFMS.

\section{REFERENCES}

BULlOCK, S. H. \& SOLIS-MAGALLANES, J. A., 1990, Phenology of canopy trees of a tropical deciduous forest in Mexico. Biotropica, 22: 22-35.

COATES-ESTRADA, R., ESTRADA, A. \& MERITT, J. r. D., 1993, Foraging by parrots (Amazona autumnalis) on fruits of Stemmadenia donnell-smithii (Apocynaceae) in the tropical rain forest of Los Tuxtlas, Mexico. J. Trop. Eco., 9: 121-124.

COTTON, P. A., 2001, The behavior and interactions of birds visiting Erythrina fusca flowers in the Colombian Amazon. Biotropica, 33: 662-669.

DEL HOYO, J., ELLIOT, A. \& SARGATAL, J., 1997, Handbook of the Birds of the World, $4^{\circ}$ vol. Sandgrouse to Cuckoos. Lynx, Barcelona.
DIRZO, R. \& MIRANDA, A., 1990, Contemporary neotropical defaunation and forest structure function, and diversity: a sequel to John Terborgh. Conserv. Biol., 4: 444-447.

FERRARI, S. F. \& STRIER, K. B., 1992, Exploitation of Mabea fistulifera nectar by marmosets (Callitrix flaviceps) and muriquis (Brachyteles arachnoides) in south-east Brazil. J. Trop. Ecol., 8: 225-239.

FORSHAW, J. M., 1989, Parrots of the World, 3rd ed. Melbourne: Lansdowne Editions.

FOURNIER, L. A., 1974, Un método cuantitativo para la medición de características fenológicas en arboles. Turrialba, 24: 422-423.

FRANKIE, G. W., BAKER, H. G. \& OPLER, P. A., 1974, Comparative phenological studies of trees in tropical wet and dry forests in the lowlands of Costa Rica. J. Ecol., 62: 881-919.

FUNCH, L. S., FUNCH, R. \& BARROSO, G. M., 2002, Phenology of gallery and montane forest in the Chapada Diamantina, Bahia, Brazil. Biotropica, 34: 40-50.

GALETTI, M., 1993, Diet of scaly-headed parrot (Pionus maximiliani) in a semi-deciduous forest in southeastern Brazil. Biotropica, 25: 419-425.

GALETTI, M., 1997, Seasonal abundance and feeding ecology of parrots and parakeets in a lowland Atlantic Forest Brazil. Ararajuba, 5: 115-126.

GRIZ, L. M. S. \& Machado, I. C. S, 2001, Fruiting phenology and seed dispersal syndromes in caatinga, a tropical dry forest in the northeast of Brazil. J. Tropic. Ecol., 17: 303321.

GRYJL, E., MARTINEZ DEL RIO, C. \& BAKER, I., 1990, Avian pollination and nectar use in Combretum fruticosum (Loefl.). Biotropica, 22: 266-271.

HEJL, S. J., VERNER, J. \& BELL, W. 1990. Sequential versus initial observations in studies of avian foraging. Stud. Av. Biol., 13: 166-173.

JANZEN, D., 1981, Ficus ovalis seed predation by Orangechinned Parakeet (Brotogeris jugularis) in Costa Rica. Auk, 98: 841-844.

KINNAIRD, M. F., 1992, Phenology of flowering and fruiting of East African riverine forest ecosystem. Biotropica, 24: 187-194.

KUBTZKI, K. \& ZIBURSKI, A., 1994, Seed dispersal in flood plain forest of Amazonia. Biotropica, 26: 30-43.

LEVEY, D. J., 1988, Spatial and temporal variation in Costa Rican fruit and fruit-eating bird abundance. Ecol. Monogr., 58: 251-269.

LORENZI, H., 1994, Árvores Brasileiras. Manual de identificação e cultivo de plantas arbóreas nativas do Brasil. $1^{\circ}$ vol. 376p. Nova Odessa, Editora Plantarum.

LORENZI, H., 1998, Árvores Brasileiras. Manual de identificação e cultivo de plantas arbóreas nativas do Brasil. $2^{\circ}$ vol. 376p. Nova Odessa, Editora Plantarum.

OLIVEIRA-FILHO, A. T., RATTER, J. A. \& SHEPHERD, G. J., 1990. Floristic composition and community structure of a Brazilian gallery Forest. Flora, 184: 103-117.

OLIVEIRA-FILHO, A. T., VILELA, E. A., CARVALHO, D. A. \& GAVILANES, M. L., 1994, Effects of soils and 
topography on the distribution of tree species in a tropical riverine forest in south-eastern Brazil. J. Trop. Ecol., 10: 483-508

PERES, C. A., 1994, Primate responses to phenological changes in an Amazonian terra firme forest. Biotropica, 26: 98-112.

PIZO, M. A., SIMÃO, I. \& GALETTI, M., 1995, Diet and flock size of sympatric parrots in the Atlantic Florest of Brazil. Orn. Neot., 6: 87-95.

POTT, A. \& POTT, V. J., 1994, Plantas do Pantanal. Embrapa, Brasília.

RAGUSA-NETTO, J., 2002, Exploitation of Erythrina dominguezii Hassl. (Fabaceae) nectar by perching birds in a dry forest in western Brazil. Braz. J. Biol., 62(4b): 877883.

RAGUSA-NETTO, J., 2004, Flowers, fruits and the abundance of the Yellow-chevroned parakeet (Brotogeris chiriri) at a gallery forest in the South Pantanal (Brazil). Braz. J. Biol., 64(4): 867-877.

RAGUSA-NETTO, J., 2005, Extensive consumption of Tabebuia aurea (Manso) Benth. \& Hook. (Bignoniaceae) nectar by parrots in a tecoma savanna in the South Pantanal (Brazil). Bra. J. Biol. 65 (in press.)

RENTON, K., 2001, Lilac-crowned parrot diet and food resource availability: resource tracking by a parrot seed predator. Condor, 103: 62-69.

ROTH, P., 1984, Repartição do habitat entre psitacídeos simpátricos no sul da Amazônia. Acta Amazonica, 14: 175221.

SICK, H., 1997, Ornitologia Brasileira. Nova Fronteira, Rio de Janeiro, 912p.
SIMÃO, I. F., SANTOS, A. M. \& PIZO, M. A., 1997, Vertical stratification and diet of psittacids in a tropical lowland forest of Brazil. Ararajuba, 5: 169-174.

STILES, E. W., 1993, Influence of pulp lipids on fruit preferences by birds. Vegetatio, 107/108: 227-236.

STILES, F. G. \& FREEMAN, C. E., 1993, Pattern in floral nectar characteristics of some bird-plant species from Costa Rica. Biotropica, 25: 191-205.

TERBORGH, J., 1986, Keystone plant resources in the tropical forest. pp. 330-344. In: Soulé M (ed.), Conservation Biology. Massachusetts, Sinauer, Sunderland.

TERBORGH, J., ROBINSON, S., PARKER III T., MUNN C. \& PIERPONT N., 1990, Structure and organization of an Amazonian forest bird community. Ecol. Monogr., 60: 213238.

TERBORGH, J. \& STERN, M., 1987, The surreptitious life of the saddle-back tamarin. Amer. Sc., 75: 260-269.

VAN SCHAIK, C. P., TERBORGH, J. W. \& WRIGHT, S. J., 1993, The phenology of tropical forests: adaptive significance, and consequences for primary consumers. Ann. Rev. Ecol. Syst., 24: 353-377.

VICENTINI, A. \& FISCHER, E. A., 1999, Pollination of Moronobea coccinea (Cluseaceae) by the Golden-winged Parakeet in Central Amazonia. Biotropica, 31: 682-696.

WHEELWRIGHT, N. T., HABER, W. A., MURRA, y. K. G. \& Guindon, C., 1984, Tropical fruit eating birds and their food plants: a survey of a Costa Rican lower montane forest. Biotropica, 16: 173-192. 